\title{
Cree Decision Making Concerning Language: A Case Study
}

\author{
Barbara Burnaby \\ Faculty of Education, Memorial University of Newfoundland, St John's, \\ Newfoundland, A1B 3X8, Canada
}

\section{Marguerite Mackenzie}

Department of Linguistics, Memorial University of Newfoundaland, St John's, Newfoundaland, ATB 3X8, Canada

In 1993, nine Cree communities on the east coast of James Bay (Québec, Canada) and inland began work on a pilot project to use Cree as the language of instruction (CLIP) in two communities, and have continued to extend this so that now Cree is the main language of instruction up to grade four (the target level) in many of the communities. We describe the complex context of language choice in schools before CLIP was implemented. In our analysis, four important threads of concern were identified: (1) locus of control (who had power in the communities and schools); (2) economies of scale (how the resources to accomplish Cree-medium teaching were created); (3) community visions of language and education (the evolution of attitudes, particularly of parents, towards the pertinent languages and their uses); and (4) the role of literacies (changes in community members' expectations of what literacy in Cree and English were good for). Our conclusion is that no simple models of language use are likely to be adequate for explaining or predicting outcomes in such complex situations. Documenting these cases longitudinally and in many facets provides unique local micro-analysis against which other circumstances can be compared.

\section{Introduction}

In 1993, nine Cree communities on the east coast of James Bay (Québec, Canada) and inland began work on a pilot project to use Cree as the language of instruction (CLIP) for grade one in two communities, and have continued to extend such a use of Cree so that now Cree is the main language of instruction up to grade four (the target level) in many of the schools in the communities. Under Cree leadership, the Cree School Board initiated CLIP as an experimental alternative to English or French as medium of instruction. English or French are subjects of instruction and the medium of one or two subjects (such as art and physical education) starting in grade two. At grade four, the main medium of instruction becomes English or French but a number of subjects, such as Cree literacy, Cree culture, and moral instruction continue to be taught in Cree. Schools in the first two communities involved, Chisasibi and Waskaganish, have had cohorts of students who have reached grade four through CLIP. Other communities joined the programme in subsequent years. After the first few years of the pilot, School Board authorities made the programme compulsory rather than optional in the communities, as long as an individual school had the personnel to staff the Cree-medium programme. Formal evaluations were conducted during the first years of operation of the grade one level (Burnaby et al., 1994) and the grade two level (Côté \& Fietz, 1995). 


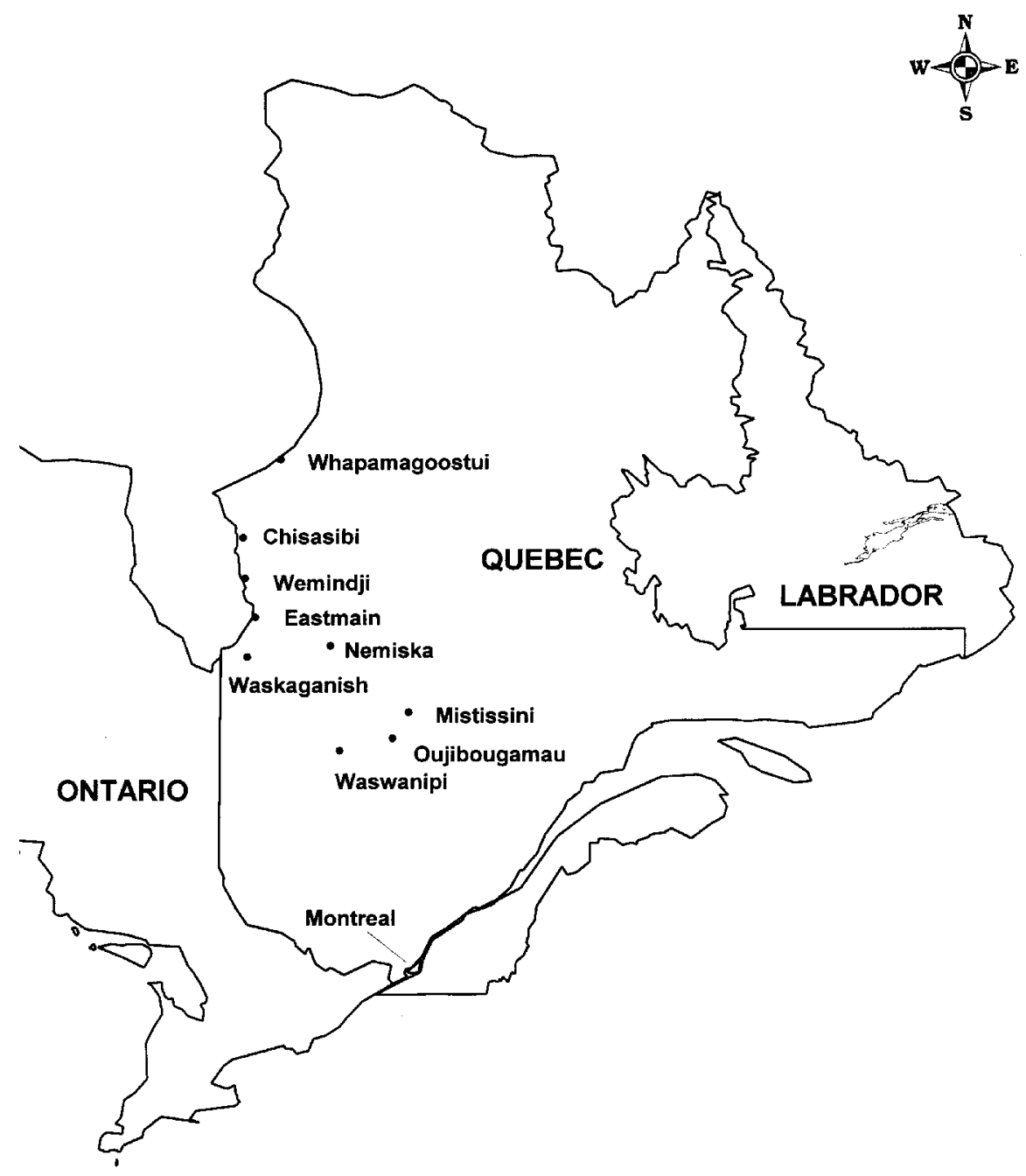

Figure 1 East Cree communities

The Crees in this area, who number about 12,000 and mostly speak Cree as a mother tongue, are a small linguistic and cultural minority embedded in the population of Canada within layers of other groups with their own linguistic and cultural agendas and struggles. The research question here is how the Crees have managed to take this assertive step in support of their language in the face of their highly competitive linguistic environment (Patrick, 1998). The process of making their choice of Cree as the language of instruction is worth documenting and exploring given (1) the small size of the group, (2) the fact that the use of languages other than English or French as the medium of instruction in formal schooling is highly unusual in Canada, (3) the fact that there is a great overall cultural difference between the Crees and most of the more populous cultures of the country, and (4) that the Crees are historically and legally designated as 
indigenous people as contrasted with the 'founding nations' of English and French and more recent immigrant groups. (See Burnaby, 1996, for an overview of Canadian language policies.)

In this situation, we see how globally documented patterns of language (particularly English) imposition by colonial powers on minority language groups (including English is best taught monolingually, the earlier English is taught the better the results, and the more English is taught the better the results) (Phillipson, 1992) have come into conflict with Unesco's 1953 declaration that, where at all possible, it is best to teach a child, at least for the first few years of schooling, in his or her mother tongue (Unesco, 1953), as well as Cummins' contention that early mother-tongue development supports not only the learning of the mother tongue but the second language as well (e.g. Cummins, 1991). These two basic positions clash in the Cree School Board's case over the issue of priorities concerning language and culture learning.

Theory from a number of academic disciplines, such as psycholinguistics, sociolinguistics, postmodern perspectives and ethnography, have made a wide variety of claims about solutions to issues in the education of linguistic and cultural minority children. These solutions tend, by the general nature of contemporary theory building, to offer unidimensional answers, such as mother-tongue education in the early grades, minority cultural reference in the curriculum, influence of views of parents and the wider community in educational decision making, having local people as teachers and the like. It is our position that actual linguistic and cultural minority situations are always so overlaid with complex factors influencing schooling and its outcomes that unidimensional explanations are impossible to prove and inevitably too simple to account for what really happens. The alternative, however, is just to leave everything to serendipity. We offer here this description and analysis of one case first of all to document it because the details of such activities are rarely made public. We also want to show that many threads of social structure within this situation and their relationships to one another would not necessarily be predicted beforehand or be likely to be found in other sites. Space limitations preclude us from elaborating the many possible comparisons and theoretical issues that could be raised from this case (cf. Hornberger, 1998; Myhill, 1999).

In this paper, background and history are outlined for CLIP in two periods: before the James Bay Agreement in 1975 which opened the way for the establishment of the Cree School Board, and between 1975 and 1990 when CLIP was initiated. Next the programme is discussed under four headings that arose during our study: locus of decision making, economies of scale, developing visions of culture and education, and literacy functions and learning. Conclusions are drawn and implications suggested.

\section{Up to the James Bay Agreement of 1975}

The Crees east of James Bay speak an Algonquian language that is part of a Cree/Montagnais (Innu)/Naskapi dialect continuum of more than 80,000 speakers that stretches from the coast of Labrador on the Atlantic to the foothills of the Rocky Mountains. In the east James Bay area, there are two dialects, north and south (MacKenzie, 1985). Traditionally, these people were hunters and gath- 
erers. They have been in contact with Europeans for more than three centuries, and the fur trade altered their economy to include trapping. After the federal Indian Act was signed in 1876, these Cree people were identified legally as Indians, and their administrative affairs were handled by the federal government. Since the federal bureaucracy and the local fur traders and missionaries were mostly English speaking, the Crees generally learned English if they acquired a European second language. Towards the middle of the 20th century, the Crees began settling permanently into communities on the coast and inland and becoming more involved in wage labour occupations, although many still practise traditional occupations full or part time (Tanner, 1981: 5-9). Given the geographic isolation of the area, they are still greatly in the majority in their part of northern Québec. A few of the communities can still only be reached by air, boat, or by roads built over ice in the winter. On the roads that connect some communities with the south, the drive to Montreal is up to 15 hours.

Christian missions were established at several places on the east of James Bay in the 19th century; missionaries and Crees from the west coast of James Bay introduced a syllabic system of writing Cree that was developed for Ojibwe by an English missionary in the 1840s (Nichols, 1996). This system was enthusiastically taken up by Algonquian language speakers who, along with missionaries, spread it to some Algonquian and other languages. For more than a century in the James Bay area, people have used syllabics to write letters and keep some records. Christian texts were widely used in church services and in families, and a small variety of other materials were printed (Murdoch, 1981). People were taught to use syllabics through the church or by family members, usually when they became adults; they rarely read it well enough to recover new meaning from unknown text. Moderate and advanced skill in using syllabics by speakers of Algonquian languages tended to be developed as a specialty among some members of families and communities rather than being expected of everyone (Burnaby \& MacKenzie, 1985; MacKenzie, 1985; Valentine, 1995).

Formal schooling in the European style was late to come to the James Bay east coast. Missionaries provided some Western-style education, especially related to literacy, and pre-1960 Canadian federal policies favoured paying Christian organisations to provide education for Aboriginal children. Starting in the 1940s, many children from this area were taken away to residential schools, a practice now deeply resented in the James Bay communities. Two of these schools were in one of the local communities and another close by at the Ontario border, but others were much further away; some children were away from their families for as long as nine years.

The special status of the native people who started as wards of the government and whose special status has been redefined and asserted by native leaders and organisations has been the major reason for these attempts at assimilation. We were taken into the residential schools and taught a value system different from what we would have learned from our parents ... fortunately for those of us from James Bay, we went back to our communities, which were still strong in the language and cultural traditions. We also retained our language by the fact that, although we were literally taken from our nomadic homes, our parents were monolingual in Cree. Even 
then, the social and cultural re-integration back into the community took several years and for some, the psychological costs were extremely high. For some families, the cost was higher, some kids never came back. (Bobbish, 1996: 244)

In the 1960s, federal control was devolving so that schooling in what was to become Cree School Board territory was still administered partially by Christian organisations, but also partially by the federal government itself, and partly by the province of Québec. In the tradition of many mission schools, at least some Cree was used as subject or medium of instruction (Preston \& MacKenzie, 1976: 16, 21; Tanner, 1981: 9), and this tradition persisted in a number of the schools under various administrations in the area. As Phillipson notes about colonising powers and language issues elsewhere, 'there was genuine uncertainty about what the essential content of primary education should be ..., reflecting the duality of the evangelizing, transforming cause [of Christian values and European worldview] and the need for sensitivity to local acceptability' (1992: 117). The provincial curriculum of Québec was the nominal standard, but there was no mechanism for coordination, much less enforcement, among and within schools. Preston and MacKenzie, in reviewing this situation in 1976, point to the basic problem in education in the area as lack of decision making (power or assertiveness) from the community level (6).

Central, of course, to issues of schooling are the personnel involved. Most of the teachers (all of the certified teachers) in the late 1960s and early 1970s were non-Aboriginals from outside the Cree communities. A few Crees enrolled in a special one-year teacher training programme in Montreal in 1969-70; from 1969 to 1976 the Department of Indian Affairs and Northern Development (DIAND) provided training for Cree people to become teacher aides. These people often were given full control over early elementary grade-classrooms (Preston \& MacKenzie, 1976:36), and sometimes taught those classes almost entirely in Cree (Preston \& MacKenzie, 1976: 44, 65). In many cases, those with teacher aide training became the instructors of Cree literacy as a subject of instruction (Tanner, 1981: 6).

Up to this point, this description has covered events and policies that were quite typical of the language and cultural situations of Aboriginal people in isolated areas in Canada and their contact with non-Aboriginal economies, missionaries, and governments. Let us turn now to actions in other parts of the country that would have a unique impact on the Cree schooling situation. In the 1960s, the focus of national politics was on relations between Francophone and Anglophone Canada, which was couched at the time largely as a language issue. In 1969, the Official Languages Act was passed federally, making Canada officially bilingual in French and English. Québec passed legislation declaring its official language as French, and other legislation followed including one highly contested act which put severe restrictions on using any language other than French as the medium of instruction in schools in the province. Also, for sovereignty and economic reasons, the Québec government started to pay attention to the vast northern region of its territory which had, up to that time, largely been administered by the federal government because the area was almost exclusively inhabited by Aboriginal peoples. One other result of the Official Languages Act 
and its context was that the teaching of French as a second language to Anglophone children across the country was radically changed and expanded, with considerable federal as well as provincial funding, as parents wanted their children to have the advantage of both official languages. In particular, the use of French as the medium of instruction (French immersion) as an effective way to teach French as a second language mostly to Anglophone children became popular (Burnaby, 1996: 173-181).

Also in 1969 and subtly connected to the debate on Anglophone/ Francophone relations, the then Minister of Indian Affairs and Northern Development, Jean Chretien, tabled a White Paper in parliament proposing that the Indian Act be abolished, on the grounds that it was racist, and that the people designated as Indians under the act (status Indians) be henceforth treated as all other citizens. Aboriginal response to this proposal was swift and almost completely negative. The most prominent was related to education and called Indian Control of Indian Education (1972), prepared by the National Indian Brotherhood, a national organisation representing mainly status Indians which had recently risen to prominence. It demanded that the federal government retain fiscal responsibility over Aboriginal education but that control should be given to the parents of Aboriginal children.

If we are to avoid the conflict of values which in the past has led to withdrawal and failure, Indian parents must have control of education with the responsibility of setting goals. What we want for our children can be summarized very briefly: ... to reinforce their Indian identity, ... to provide the training necessary for making a good living in modern society. (National Indian Brotherhood, 1972:3)

In this document, detailed requirements were set out for the central role of Aboriginal languages as medium and subject of instruction in education for first-and second-language learners (14-16). The rationale was for better comprehension of content in the early grades, better identity reinforcement, and reversal of overall trends towards Aboriginal language loss.

In the early 1970s, then, these influences on Aboriginal education were in place, as was the fact that Aboriginal language use was clearly declining. According to the census, the percentage of people who identified themselves as being of Aboriginal ancestry and having an Aboriginal language as a mother tongue dropped from $75.7 \%$ in 1961 to $57.1 \%$ in 1971 (Burnaby \& Beaujot, 1986: 36). With very little coordination, Aboriginal languages were beginning to be introduced as subjects of instruction (as first or second languages) in various places across the country. To give some Algonquian examples, Wasacase (1976) and Kirkness (1976) promoted a more ambitious model of Aboriginal language instruction in which the Aboriginal language would be the medium of instruction in the first few years of school while English was slowly introduced until it was the medium for about half the school day by grade four. This model was ambitious because the Aboriginal languages had virtually never been used before in Western-style education so that pedagogical approaches, trained teachers, curriculum, materials, and school support services appropriate for them had never been developed (Kirkness, 1976). In the early 1970s in Manitoba, this approach was implemented in several communities in the north where chil- 
dren came to school speaking Cree. The programme survived for a number of years, particularly in Cross Lake, but was reduced to subject of instruction eventually. In Ontario, in concert with the Manitoba initiative and also reflecting the French immersion model, an Ojibwe community on Manitoulin Island had an Ojibwe immersion programme for several years (Wasacase, n.d.).

In Québec in the early 1970s, a similar model to those of Wasacase and Kirkness was promoted by Gagné (1979) for Aboriginal languages in that province. In 1972, the Amerindianisation of the School project was created under the leadership of the Québec office of DIAND, which developed the training of Aboriginal teachers to teach through the medium of their languages in their schools (Bourque, 1979; Gagné, 1979). From 1972 to 1976, it offered summer programmes first at Chicoutimi and then at Manitou College in La Macaza, Québec, to train teachers under the auspices of the University of Québec at Chicoutimi. In addition, this programme offered courses and supervision of candidates in their home communities during the winter. The first Crees who attended this programme had been Cree language teachers. An emphasis in this programme was on Aboriginal language materials development and underlying linguistic work such as dictionaries and orthography standardisation. The need became evident for Aboriginal language speakers trained in research and development, so a programme was created to train 'technolinguists' in both linguistics and education methods. After several years, the main programme was organised into Stream A (for teachers to teach through the medium of their Aboriginal language) or Stream B (for teachers to teach Aboriginal children through English as a second language) (Preston \& MacKenzie, 1976: 104-5). Also in this year, DIAND started funding Cree as a subject of instruction classes in its schools (Curriculum Development Team, 1979: 5).

From 1973-76, an exceptional undertaking, the Cree Way Project, operated out of Waskaganish, a community in the James Bay Cree area, to produce teaching materials and resources, mostly in Cree, for schools. The intent was to make materials available to students and teachers that reflected the local language, culture, and approach to learning. This productive operation was at arms length from government school authorities (Preston \& MacKenzie, 1976: 66-70; Tanner, 1981:14-16). (It was later incorporated as part of the Cree School Board).

Thus, by about 1975 a variety of forces were working to influence possibilities for the use of language in schools in the east James Bay area. Old colonial and more recent factors maintained the value of English; new political trends raised French on the horizon as a matter of administrative and economic importance, and Aboriginal and non-Aboriginal parties alike were promoting the potential of developing Aboriginal languages through the schools. These were all to come into play when extensive changes were made through the James Bay Agreement of 1975.

\section{The James Bay Agreement (1975) and Afterwards}

At the same time as pursuing its interest in asserting sovereignty over arctic Québec where Crees and Inuit live, the Québec government also decided to exploit the economic potential of the broad rivers which flow westwards into 
James Bay by building hydroelectric dams. This meant negotiating with the federal government, the Crees and the Inuit to work out its jurisdiction in the area. In the end, two large areas were identified, one for the Crees and the other for the Inuit. Each was to be administered under a local government rather like that of a municipality. In 1978, the newly established Cree Regional Authority (the Cree Chiefs and the Grand Chief of the Crees) formed the Cree School Board. It operates basically as a regular provincial school board, overseen by a Council of Commissioners elected by each community, but is released from a number of provincial regulations to permit, among other things, the use of Cree as a medium of instruction in schools (Tanner, 1981: 16-19). Given the rigour with which Québec has implemented its law to have French as the medium of instruction for almost all children in the province, this concession was not inconsiderable. On the other hand, Québec could hardly deny such a language right to an indigenous minority in its territory even though it did not extend to non-indigenous minorities. From the late 1970s, the option of having French or English as a medium of instruction was developed and most Cree School Board communities offer both.

While teacher training for some Cree candidates continued with the UQAC/DIAND programme, a new agreement was reached with McGill University for the training of more Cree students to be teachers, in part to develop language-specific training (McAlpine \& Herodier, 1994). This training continued to involve supervision of teachers-in-training in their home communities as well as the system of offering many of its courses in the communities as well. The Stream A and Stream B system was maintained.

The new Cree School Board was given considerable latitude through the James Bay Agreement to create a curriculum based on local language and cultural interests within the basic curriculum framework for Québec schools. It commissioned a position paper from local and academic specialists on language of instruction that was submitted in 1979. Following the vision of Aboriginal language medium of instruction for much of elementary schooling for Aboriginal language-speaking children as set forth in the Amerindianisation Project and by other educators worldwide (Curriculum Development Team, 1979:9-11), this paper proposed four potential programme types, ranging from no Cree-medium instruction to all Cree medium instruction from kindergarten to the end of high school. Although the paper left the choice among these open, it made the option of having Cree as the medium of instruction for the primary grades, with Cree as the first language of literacy and continued use of Cree-medium instruction, appear more attractive than the other options. In this document there was also an extended discussion of how Cree cultural elements could be incorporated into the curriculum (18) and the need for Cree language and materials development to support a Cree medium program (57-66). It noted that the Council of Commissioners had already adopted a policy whereby Cree would be the language of instruction for kindergarten and pre-kindergarten (17). The Council also had allowed for the teaching of Cree literacy as a subject of instruction, and for Cree to be the medium of instruction for moral and religious instruction and for physical education (Tanner, 1981: 20-21).

It should be noted that the Kativik School Board, the parallel Inuit school board to the Cree School Board as created by the James Bay Agreement in arctic 
Québec, began a gradual increase in the use of Inuktitut up to grade four community by community, grade by grade, through the use of classroom assistants and teachers in training while more teacher training, research, and curriculum development was continuing (Stairs, 1985: 44-47, 1994). Also, between 1982 and 1987, the Innu (Montagnais) community of Betsiamites on the north shore of the St Lawrence River experimented with an Innu medium of instruction programme with transition to French from pre-kindergarten to the grade three level that was terminated with the final year of the first cohort (Drapeau, 1992).

Although the Cree School Board worked towards the development of Cree medium of instruction with gradual transition to English or French, there were almost immediate problems with this approach. Tanner, an anthropologist who had worked extensively in the region, was hired in 1981 to research the background of the issue and to survey parents' attitudes. His summary of grounds for opposition to the programme included: Cree-speaking teachers with full certification to teach in regular classrooms (i.e. not just Cree as a subject of instruction) were trained to teach in English or French, not Cree; only two of those eleven teachers knew the Cree writing system; materials were scarce and curriculum inadequate; and parents expected English or French to be taught from the beginning to prepare children for later school demands (Tanner, 1981: 23). In his survey, Tanner found that parents were not consistently in favour of any one of the four options developed by the Curriculum Development Team, but that those in communities with more traditional economies tended to prefer the options with more Cree, while those with less traditional economies tended towards more English/French (77). Parents, he notes, were particularly worried about their children becoming literate in Cree before English or French (19). As had Preston and MacKenzie in 1976, Tanner focused his analysis of the issues on the need for consistent, clear goals for the language programme and lack of integration with the goals of the rest of the school curriculum (75). A set of community meetings were held to discuss Tanner's report. At one of those meetings a community member described the problem of learning multiple languages as if learning three languages required three lifetimes.

Between 1981, with Tanner's report, and 1993, when the CLIP programme was initiated in two communities, the use of Cree in the Cree School Board schools remained very little different from what it had been in the early 1970s (Tanner, 1981: 16-17). Cree was sometimes used in kindergartens; literacy in Cree was taught as a subject; and Cree was the medium of some subjects such as traditional skills, religion, and physical education. However, other changes were taking place that could alter the conditions for Cree-medium instruction. Work begun at the Amerindianisation of the Schools project and called for by the Curriculum Development Team (1979) on orthography standardisation and training of technolinguists continued through various phases resulting in a dictionary, various teacher support materials, and a great deal of awareness about language issues on the part of local teachers and curriculum support professionals (MacKenzie, 1985). The teacher training programmes, transferred to McGill University, continued to certify local people as fully credentialled teachers, who then gained experience in the schools (McAlpine \& Herodier, 1994). In the early 1990s, a language teachers' specialisation was initiated within the teacher training programme. The old Stream A had been mainly used for 
teachers who would teach Cree literacy as a subject of instruction. However, its original intent as a programme for teachers to teach in Cree as a medium of instruction gained interest, and the new specialisation offered support for the literacy and pedagogical needs of B Stream teachers contemplating Cree medium teaching. Teachers and pedagogical counsellors at the Cree School Board participated in the development of an English as a second language, language arts programme for Aboriginal children in northern communities (Burnaby, et al., 1986-88). This programme served not only as a set of materials for use in Cree School Board English classrooms but also as a model of language arts and curriculum design. Overall, the Cree School Board was gaining in experience and was resolving its general curriculum issues. A document was produced outlining Cree values and knowledge that community members agreed should be part of school education. These values were integrated with the framework of the Québec Ministry of Education's (MEQ) curriculum. In addition, the communities settled economically, politically, and socially into their new situation under the Grand Council of the Crees.

About this time, Bobbish (1996, but originally published in 1992), Director of Education Services of the Cree School Board, describes the Crees as concerned about diminishing levels of Cree language maintenance.

We are now into the first generation of children who went to school to be instructed in a language, French or English, without having a strong base in the Cree language. The reason why parents up to a couple of years ago opted for this were:

1. The notion that the child would have a better chance of succeeding academically the sooner he/she was introduced to the second language and hence would be prepared to continue to higher education for better job opportunities; and

2. That the parents would teach Cree anyway because Cree was spoken at home. (245)

He also notes that this acceptance of English/French-medium education on the part of parents has not resulted in much educational success, that Cree has been further weakened by the advent of electronic media (telephones, television and radio) in the communities in 1975, that children's Cree identity has been weakened by immersion from an early age in an irrelevant curriculum, that Cree language and culture taught as subjects of instruction were just add-ons to the curriculum, and that teaching children literacy in Cree syllabics was ineffective because the children were not adequately fluent in oral Cree first (245-247).

In December 1988, the Council of Commissioners of the Crees decided to implement its education plan by creating a Cree language policy. Also, a group of people in Chisasibi strongly lobbied the Cree School Board to institute a school programme using Cree as the language of instruction, at least for the first few grades. It is interesting to note that it was on account of opposition to such a program from that same community that the Tanner survey was commissioned in 1980 by the School Board, and that the policy to use Cree as the medium of instruction in kindergarten and pre-kindergarten was abandoned (Tanner, 1981: 23). Nonetheless, in 1992 it was agreed that a pilot Cree-medium programme 
would be set up in Chisasibi and Waskaganish. For a year, teachers were prepared, a curriculum combining the MEQ's framework, the Cree values curriculum, and a language arts approach was created, and materials were developed, adapted, or translated. The evaluation of the first year noted the success of the programme but listed predictable issues yet to be dealt with, such as the need for more literature in Cree, language support for the teachers, community education to involve other teachers, parents and others in the programme, the need for various normal educational supports (supply and remedial teachers, methods of student evaluation), better planning for future years and revisions, better integration with other school programmes, and so on (Burnaby, et al. 1994). In the second year, grade two levels were added in the original schools and grade one was started in various others. The evaluation for that year expressed similar overall satisfaction with the program and general needs as well. The programme has continued in this vein. After the first few years of success as a pilot, the Council of Commissioners decided to make the programme mandatory in all schools in the board except where there were not sufficient qualified personnel to staff it.

\section{Discussion}

\section{Locus of control}

In a complex situation such as this one, there are many interesting facets. From the perspective of the most rudimentary politics of the situation, it is clear that simply having local control over certain decision making in school jurisdiction was not enough to bring about a major change like medium of instruction. And, of course, local control was by no means absolute. Because of the Crees' belief in the importance of a formal, Western-style education for their children, they agreed in 1975 to work within established mainstream frameworks for education, and it was undoubtedly working out many of the parameters of that control that occupied the School Board in the first few years. According to Bobbish (1996: 245),

the immediate priorities [of the Cree School Board after its inception] were appropriate facilities in the way of schools, teachers' residences and other pertinent facilities. For many years the actual question of quality of education was not confronted mainly because of these practical problems and other problems related to the legal interpretation of the education section of the James Bay Agreement.

Because the Crees were embedded, at least to some extent by their own choice, in the mainstream education system, they had to work out how to operate within its many constraints, but at least they did not have to create an educational structure from scratch. Since they could not avoid the restrictions and perspectives of external parties in the education system, many mainstream institutions and people such as the MEQ, the university that provided the teacher training, the linguist and others who worked on the writing system and dictionary, the group who developed the English language arts programme, and others, continued to influence the direction of eventual initiatives. 
Despite the restrictions, the Crees gained significantly in the formation of the Cree School Board in that direct community involvement in educational decision making was established for the first time. Because each of the settlements range in size from about 500 to 3000 , community pressure is direct and immediate. Through the School Board, parents had direct input into the choice of leadership and decisions taken. It is evident from Tanner's survey results in 1981 that the communities were not ready to accept the proposal made by the Curriculum Development Team in 1979, no matter how well researched it was from a mainstream perspective. It took time for the community to come to terms with certain changes; they could not be implemented by fiat. In its first decade the Cree School Board had time to establish itself and to create a credible infrastructure. Once the parents had confidence in the capacity of the School Board, they were prepared to take a risky move.

\section{Economies of scale}

In addition to issues of uniting community and leadership concerning the adoption of a programme of vernacular language in the school, Unesco (1953) identified that getting enough educational materials developed in the language, getting enough general reading materials prepared, and getting enough teachers trained were crucial potential obstacles to vernacular education. The success of change from within is related not only to leadership or control, but also to the essential human and material resources available for the task. Looking at reports on education in the Cree area of northern Québec before about 1990 would lead one to think that educational change in the direction of Cree-medium programmes was doomed to failure. As noted above, there was no increase or qualitative change in Cree language use in the schools between 1975 and 1989 (see Tanner 1981: 16-17). In addition, a considerable amount of the Amerindianisation vision was not realised in teacher training because Stream A, supposed to train teachers to teach regular classes through the medium of an Aboriginal language, turned into a stream to teach Aboriginal teachers to teach their languages as subjects of instruction (Tanner, 1981: 11-12). The Cree Way Project produced a considerable amount of material in the 1970s, but this did not appear to be making much impact.

Nevertheless, the development of Cree literacy through standardisation and language support documents continued during the 1980s. This process involved and directly or indirectly trained a significant number of teachers and other school-related personnel. The School Board had at its disposal a significant number of local teachers who were completely trained and well experienced in the classroom. The Cree values curriculum, created by local elders and accepted by the community and School Board, put emphasis on the Cree perspective on the world for teachers, children, and parents. The technolinguists / pedagogical counsellors were gaining experience and confidence in curriculum work as the Cree School Board matured and its programmes stabilised. The increasing number of Cree teachers in charge of English- and French-medium classrooms were gaining experience with the entire range of subjects for their grade, including their involvement in the development of the Circle ESL curriculum and materials which were later printed in the new standard Cree syllabics; the resulting materials formed a central part of the original core of the CLIP 
programme. Therefore, in the long run, all the pieces were in place when the various political and social elements were ready to try Cree-medium instruction again. It appears that the educational materials necessary for Cree-medium instruction were on the horizon in 1990 as a result of work done for Cree subject of instruction classes, from the Cree Way Project, and in general curriculum organisation in the School Board. The Cree Way materials also contributed towards the supply of general reading materials; however, both evaluations of CLIP have noted the need for more such material, including the production of existing Cree Way books in the standardised orthography. Finally, the teacher training programme was well established and could accommodate the renewed request for support for teachers in Cree-medium classrooms. In the CLIP evaluations, there were calls for various means of on-going support for the teachers in CLIP classrooms, but it is clear that their basic training was adequate for and suitable to the work.

Looking across Canada at other initiatives to use an Aboriginal language as medium of instruction in schools, some have clearly lasted longer than others. The programmes in Betsiamites (population about 1200) in the 1980s and six communities (no population estimate) in northern Manitoba in the 1970s, which were in communities where most children came to school speaking the Aboriginal language at least to some extent, lasted about five years. In both these situations, the communities had some degree of local educational autonomy but not to the extent of the school board status of the Cree School Board. In the Northwest Territories (NWT), where Aboriginal people are in the majority, the Department of Education promoted the use of Aboriginal languages as medium of instruction in the early grades from the late 1970s. The Inuit in the NWT (population about 18,000 ) have pursued the same kind of gradual implementation of Inuktitut-medium instruction as did the Kativik School Board (population about 7000), especially in the eastern regions. In all these cases there was external support and local mobilisation of resources on the part of fluent speakers for teacher preparation, orthography standardisation, and materials development in advance of the implementation in the classroom, and in the case of Manitoba, there was initial cooperation among a number of relevant communities. Kativik has the same local control, and the NWT has similar local control as that of the Cree School Board.

Aboriginal languages have been used as medium of instruction in a number of communities in which the children come to school speaking very little or none of the local Aboriginal language. In West Bay (population about 800) on Manitoulin Island, the 1970s Ojibwe immersion project mentioned above had few external supports available or native-speaker resources, nor a great deal of local control over the administration of education. This project lasted a year and a half. Two large Iroquoian communities, Kahnawake near Montreal (population unknown because census data are incomplete) and Six Nations near Brantford, Ontario (population about 8000) initiated immersion programmes in Mohawk (early 1980s) and Mohawk and Cayuga (mid-1980s) respectively. Both these communities had a long history of assertiveness with respect to local control of education, and both were able to mobilise considerable support from local speakers of the languages even though the numbers of speakers in the communities were relatively few proportionately. Also, both communities are large enough that the 
programme could remain optional since there were a number of classes for each grade. The Kahnawake programme has since dwindled after graduating several cohorts who reached grade twelve, but the Six Nations programme is still operating after about 14 years.

Information about Aboriginal language programmes in Canada is largely ephemeral and few case studies, evaluations, or other descriptions are published. But on the foregoing largely piecemeal and anecdotal information, it still seems worth speculating that the success of Aboriginal language medium of instruction programmes is at least in part related to three factors: the human resources in the community which can be rallied in direct support of the programme; the extent of relevant external support (e.g. specialised teacher training, orthography development, curriculum expertise); as well as the level of local control over the administration of education. Raising local control in communities with small populations may not be enough to encourage innovation because there are insufficient people to take on the work and fill all the roles. This possibility is a matter for concern in Canada where the amount of local control of education in Aboriginal communities has increased a great deal over the past decade or so, but where many of the communities are very small and not always affiliated in significant ways (as through a school board or otherwise) with other communities with which they can share resources. Also, it may be harder for communities to attract mainstream education supports for their specialised needs (e.g. teacher training) if they are small or lack a status from which they can call on resources from other sources.

\section{Community visions of language and education}

Aside from the matter of who is making the decisions and what their resources are, this story tells a great deal about language attitudes among all the stakeholders. One could begin by looking at the languages that parents take seriously as needed by their children for their future lives. Tanner's 1981 survey indicated that parents expected that learning English would be a central part of the education for their children. A considerable number of parents were prepared to have Cree eliminated from schooling altogether. Whatever such parents expected would happen to their children's skills in Cree, they clearly put their priority on English in education. For them it would seem that they had to make a choice between Cree or English. Howard (1983:8), writing about language programmes for the Dene in the Northwest Territories, mentions a more politically based objection, namely 'opposition from native people who, not understanding the concept of bilingual education, apparently thought there was a move afoot to shut them out of the economic life of Anglo Canada'. Tanner (1981: 77) lists, as one of three priorities that Cree parents saw as impediments to a Cree-medium programme, the need to raise formal education standards. In other words, formal education success and English achievement were strongly linked, but Cree was not seen as a contributor and perhaps even a hindrance. An additional complication to this picture was the rapidly rising profile of French in Québec Cree territory since the early 1970s as Québec moved to gain political and economic control over that part of the province. Tanner (1981:77) gives the desire of Cree parents for third language education (i.e. French in addition to English or 
vice versa) as another hindrance in the parents' minds towards the implementation of Cree-medium instruction.

People usually have opinions about how learning does and should take place. As noted above, Phillipson (1992) has shown the persistence of the influence of the former imperial powers on the learning of colonial languages as well as methods of teaching the language monolingually as early and as much as possible. Tanner (1981:24) indicates that the expectations of parents seemed to conform most closely with a similar kind of education programme, one that currently tended to exist in the schools. The simple point to be made here is the inertia of the ways things have always been done augmented by the lingering authority of the position of earlier Euro-Canadian influences.

In juxtaposition to this entrenched view of how language is learned (in schools at least) is the problem that the position in favour of using the vernacular language as a medium of instruction has been difficult to accept (for at least the Crees and Montagnais) in that it promises not only the maintenance and development of the vernacular language but also better second language learning with less time spent directly on it. This promise is based on the notion that skills learned relatively easily in the first language will transfer readily to the second language. It also assumes that children will adapt better to early schooling in their first language than in a second (e.g. Cummins, 1991; Fillmore, 1991). Unesco in 1953 recognised this issue as a major concern in the implementation of vernacular education programmes. Drapeau (1992) shows in detail, in her analysis of a programme to use Montagnais as the medium of instruction similar to CLIP, that this notion of transfer was not convincing to parents, who put pressure on teachers to include French as well as Montagnais in the grade one Montagnais-medium class. Preston and MacKenzie (1976) and Tanner (1981) give various examples of Cree people's fears that time taken for Cree in the curriculum would mean reducing valuable time needed for good English language learning. Persuading community members that this kind of transfer is possible is difficult without opportunities to demonstrate the results.

The exact relationship in the minds of Cree community members between language, economic potential, and success in schooling cannot be teased out here, but there is no doubt that it is strong. Something must have happened in the language context of the Cree area to have changed priorities in the minds of parents between 1980 and 1990. It seems likely in 1980 that Cree might have been eliminated from the school but instead that it has regained priority in recent years. Bobbish says,

It is very evident that the preservation of the Cree language is something that has to be dealt with concretely, both at the school and community level ... We are aware of the fact that we cannot continue with the full use of a curriculum that has been used to discredit our sense of identity and therefore maligned our ultimate purpose of preserving our language and culture. (1996: 245)

The community appears to have accepted the value of Cree both as a language of transition in school and as a goal of education for preserving a valuable cultural resource. Unlike many Aboriginal communities in Canada, those of the James Bay Cree have taken substantial action through a change in the medium of 
instruction in schools to arrest language loss at a crucial time, especially in circumstances in which there were still many speakers and when at least some children are learning it as a mother tongue. From the information we have about these events, the catalyst for this important change of perspective on the part of community members (for example, leadership, control of education, presence of human resources, external influences, or other factors) is not clear. The answer to this question could revolutionise the field of minority language maintenance.

\section{The roles of literacies}

There is no doubt that both the form and social functions of literacy in English and French relative to those of Cree are vastly different in James Bay communities. (See Burnaby and MacKenzie (1985) for a description of literacy in all three languages in Waskaganish.) With respect to attitudes towards language and language learning, the Cree parents seemed to feel specifically that their children should learn literacy in English or French first rather than in Cree. Drapeau (1992) considers this a likely reason for the parents pressuring the teacher in a grade one Montagnais medium class to teach French as well as Montagnais and to offer remedial classes in French reading outside of school hours. Tanner (1981: 19) comments 'the main difference between Cree expectations and the concept of Bilingual Education is over the role played by mother tongue literacy in the latter approach'. While Cree parents could see the point of using oral Cree in school to explain concepts and do classroom management, they were not as sure that literacy in Cree first would be appropriate. In the case of the CLIP programme at present, there is no doubt about the fact that initial literacy in Cree is a central part of the programme. According to Bobbish:

We must acknowledge that native languages, being oral languages, are the foundation of an oral culture and that this cannot be compared to the literate culture of French or English that has dominated our communities and our classrooms ... Our oral cultures existed by holistic knowledge of the traditions of oratory and story telling ... On the other hand, the literate culture of French or English as we know it is compartmentalized knowledge and it is acquired by 'education' ... it incorporates a different value system. From our observations and experience, we are able to combine the two because we cannot deny the impact of non-native society on our lives and cultures. (1996: 247)

What changed in the community and its context to allay parents' fears about the role of Cree literacy in the CLIP programme, and the potential for transfer to English and French from Cree language literacy? The orthography development and dictionary projects had a high profile in several of the communities during the 1980s. Perhaps people could see, through these activities, an intrinsic value in Cree literacy that had not been evident before (MacKenzie, 1985). As teachers and others gained skills in literacy through the orthography workshops and adult literacy classes, perhaps some of their confidence in these skills impressed the parents. Or perhaps the unusual nature of the writing system came to be associated by the Cree with the unique value of the language itself (Burnaby \& MacKenzie, 1985). As with the reasons for the change of attitude towards the acceptability of the language as a whole as the language of instruction in school, 
it is not clear why the communities changed their perspectives about the possibility that syllabics could successfully be used as the first language of literacy. The answer to this question, too, would have value in the field of minority language preservation and development.

\section{Conclusions}

In this case study, we have shown that, after a period of painful submersion in highly assimilative forms of education for a number of decades, the Cree communities in question, and their leadership, have been able to take advantage of a number of factors to create a unique situation. This promises to lead towards their stated goal for their children of both succeeding in mainstream formal education and retaining their language and culture. Some of the contributing factors came from mainstream influences. A few were aimed at the same goals of promoting Cree language and cultural development, such as the Amerindianisation project of DIAND, the subsequent training for Cree subject and medium teachers and community language workers, and support for orthography and literacy work. Other factors were not intentionally helpful, such as the role of language in Québec and national politics, Québec's expansion into the north, or the James Bay Agreement and the resulting formation of the Cree Regional Authority, but they undoubtedly contributed to the outcome. However, the Crees were certainly not passive in the process. Good leadership took the situation in hand and realised the potential of having their own School Board work in the communities' interests. If they had not, then the parents would not have accepted the School Board's second attempt to make Cree the language of instruction. The Board wisely launched it as a pilot project to build further confidence in the model. If we are to hope for more examples of this kind of creative synthesis of diverse language and cultural elements in education, then we need to document such struggles and successes much more, examine them better and, crucially, we must support them with every resource we have. Particularly, we need to maintain data longitudinally to reflect the on-going nature of linguistic and cultural change. While studies of unique combinations of factors in separate cases will not bring about a singular model of 'how to do it right', they will still provide awareness of crucial factors that may need attention in new situations.

\section{Correspondence}

Any correspondence should be directed to Dr Barbara Burnaby, Dean, Faculty of Education, Memorial University of Newfoundland, St John's, Newfoundland, Canada, A1B 3X8 (bburnaby@mun.ca) and Dr Marguerite MacKenzie, Head, Department of Linguistics, Memorial University of Newfoundland, St John's, Newfoundland, Canada A1B 3X8 (mmackenz@mun.ca).

\section{References}

Bobbish, J. (1996) The future of the Cree language. In J. Maurais (ed.) Québec's Aboriginal Languages: History, Planning and Development (pp. 244-249). Clevedon: Multilingual Matters.

Bourque, V. (1979) Amerindianisation Project Report 1972-1979. Québec City: Department of Indian and Northern Affairs. 
Burnaby, B. (1996) Language policies in Canada. In M. Herriman and B. Burnaby (eds) Language Policies in English-Dominant Countries: Six Case Studies (pp. 159-219). Clevedon: Multilingual Matters.

Burnaby, B. and Beaujot, R. (1986) The Use of Aboriginal Languages in Canada: An Analysis of 1981 Census Data. Ottawa: Social Trends Analysis Directorate and Native Citizens Directorate, Department of the Secretary of State.

Burnaby, B., Faries, E., Fietz, O. and McAlpine, L. (1994) Cree Language of Instruction Grade One Program: Report of External Evaluators. Chisasibi, Québec: Council of Commissioners of the Cree School Board.

Burnaby, B. and MacKenzie, M. (1985) Reading and writing in Rupert House. In B. Burnaby (ed.) Promoting Native Writing Systems in Canada (pp. 57-81). Toronto: OISE Press.

Burnaby, B., McInnes, J., Guebert, L., Izatt, M., Speares, J. and Upper, M. (1986-88) Circle: An ESL and Reading Program for Cree and Ojibwe Speaking Children. Markham, Ontario: Fitzhenry and Whiteside.

Côté, J. and Fietz, O. (1995) External Evaluation Report on the Cree Grade Two Pilot Program. Chisasibi, Québec: Council of Commissioners of the Cree School Board.

Cummins, J. (1991) Interdependence of first and second language proficiency in bilingual children. In E. Bialystock (ed.) Language Processing in Bilingual Children (pp. 70-89). Cambridge: Cambridge University Press.

Curriculum Development Team (1979) Position Paper: Bilingual Education, Cree as a Language of Instruction. Vald'Or, Québec: Council of Commissioners of the Cree School Board.

Drapeau, L. (1992) Rapport Final Sure Le Projet-pilot de Betsiamites: Étude Longitudinale (1982-1990). Montreal: Département de linguistique, Université du Québec à Montréal.

Fillmore, L.W. (1991) When learning a second language means losing a first. Early Childhood Research Quarterly 6 (3), 23-346.

Gagné, R. (1979) The maintenance of Native languages. In J. Chambers (ed.) The Languages of Canada (pp. 115-129). Montreal: Didier.

Hornberger, N. (1998) Language policy, language education, language rights: Indigenous, immigrant and international perspectives. Language in Society 27, 439-458.

Howard, P. (1983) History of the uses of Dene languages in education in the Northwest Territories. Canadian Journal of Native Education 10 (2), 1-18.

Kirkness, V. (1976) Manitoba Native Bilingual Program: A Handbook. Ottawa: Indian and Northern Affairs, Education and Cultural Development.

MacKenzie, M. (1985) Spelling reform among the James Bay Cree. In B. Burnaby (ed.) Promoting Native Writing Systems in Canada (pp. 49-55). Toronto: OISE Press.

McAlpine, L. and Herodier, D. (1994) Schooling as a vehicle for Aboriginal language maintenance: Implementing Cree as the language of instruction in northern Quebec. Canadian Journal of Education 19 (2), 128-141.

Murdoch, J. (1981) Syllabics: A Successful Educational Innovation. Unpublished masters dissertation, University of Manitoba.

Myhill, J. (1999) Identity, territoriality and minority language survival. Journal of Multilingual and Multicultural Development 20 (1), 34-50.

National Indian Brotherhood (1972) Indian Control of Indian Education. Ottawa: National Indian Brotherhood.

Nichols, J. (1996) The Cree syllabary. In P.T. Daniels and W. Bright (eds) The World's Writing Systems (pp. 599-611). Oxford: Oxford University Press.

Patrick, D.R. (1998) Language, power, and ethnicity in an Arctic Québec community. Unpublished doctoral dissertation, Ontario Institute for Studies in Education of the University of Toronto.

Phillipson, R. (1992) Linguistic Imperialism. Oxford: Oxford University Press.

Preston, R. and MacKenzie, M. (1976) A Comprehensive Study of the Educational Needs of the Communities Comprising the Grand Council of the Crees (of Québec). Val d'Or, Québec: Grand Council of the Crees of Québec. 
Stairs, A. (1985) The developmental context of Native language literacy: Inuit children and Inuktitut education. In B. Burnaby (ed.) Promoting Native Writing Systems in Canada (pp. 33-48). Toronto: OISE Press.

Stairs, A. (1994) Indigenous ways to go to school: Exploring many visions. Journal of Multilingual and Multicultural Development 15 (1), 63-76.

Tanner, A. (1981) Establishing a Native Language Education Policy: A Study Based on the Views of Cree Parents in the James Bay Region of Québec. Val d'Or, Québec: Grand Council of the Crees of Québec.

UNESCO (1953) The Use of Vernacular Language in Education. Paris: Unesco.

Valentine, L. (1995) Making it Their Own: Severn Ojibwe Communicative Practice. Toronto: University of Toronto Press, Anthropological Horizons Series.

Wasacase, I. (n.d.) Bilingual 'Immersion' Native Language Ojibwe Pilot Project, West Bay, Ontario. Ottawa: Department of Indian Affairs and Northern Development.

Wasacase, I. (1976) Native bilingual-bicultural education programs. Dialogue 3 (1), 2-8 (publication of the Indian and Eskimo Affairs Program of the Department of Indian and Northern Affairs). 